\title{
Stabilisation of tetrabromo- and tetrachlorosemiquinone (bromanil and chloranil) anion radicals in crystals $\dagger$
}

\author{
Krešimir Molčanov, ${ }^{\text {a }}{ }^{\text {Biserka Kojić-Prodić, }}{ }^{a}$ Darko Babić, ${ }^{\text {ab }}$ Dijana Žilić ${ }^{\mathrm{a}}$ and Boris Rakvin ${ }^{\mathrm{a}}$
}

Received 3rd May 2011, Accepted 18th May 2011

DOI: $10.1039 / \mathrm{c} 1 \mathrm{ce} 05513 \mathrm{e}$

Crystal structures of alkali salts of tetrahaolgenosemiquinone anion radical acetone solvates and their solvent-free salts are determined. p-Semiquinone anion radical reveals enhanced aromaticity of the ring compared to the quinone. A pair of $\mathrm{p}$-stacked radical anion ( $\mathrm{p}$ semiquinone) rings occurs in crystal structures of potassium and rubidium salts of tetrachlorosemiquinone anion acetone solvates and their potassium tetrabromo analogue. The ring centroid separation distances are about $3.2 \AA$ and carbon-carbon contacts between the contigu ous rings are $0.3 \AA$ shorter than the sum of van der Waals radii. The spin-coupling of the two unpaired electrons between the two anion radical rings (forming a stacked dimer) correlates with the diamagnetic property of the crystals. Magnetic properties of alkali salts of tetrahaolgenosemiquinone anion radical acetone solvates were examined by electron paramagnetic resonance spectroscopy.

\section{Introduction}

Quinones and semiquinone radicals undergo easily reversible oxidation-reduction reactions and they are excellent electron carriers. Due to influence of the functional groups, quinones may have various values of the standard redox potential. The oxidation potential of the quinones with electron-donating groups such as $-\mathrm{OH}$, is lower, and with electronwithdrawing groups such as $-\mathrm{Cl}$ and $-\mathrm{NO} 2$, the potential becomes higher. These unique electron properties of quinones are exploited for syntheses, both, in laboratory and by nature in vivo. ${ }^{1,2}$ Substituents on the quinoid ring modify electron density affecting oxidation potential and stability of the semiquinone radical (Scheme 1). Perhalogenated benzoquinones are easily reduced and their radicals are rather stable; four electronegative substituents make electron density in the ring significantly lower. Sodium and potassium salts of tetrachlorosemiquinone anion radical were first prepared in 1912 by Torrey and Hunter ${ }^{3}$ by reaction of alkali iodide and tetrachloroquinone in acetone. Green salts with formulae $\mathrm{NaC}_{6} \mathrm{C}_{14} \mathrm{O}_{2}$ and $\mathrm{KC}_{6} \mathrm{C}_{14} \mathrm{O}_{2}$ precipitated from cold acetone but quickly decomposed upon heating. During the last fifty years perhalogenosemiquinones were studied by various techniques: EPR, ${ }^{4-6} \mathrm{UV} / \mathrm{Vis}^{7}$ and IR/Raman spectroscopy ${ }^{8-11}$ and computational methods. ${ }^{12-15}$ Several charge-transfer systems involving tetrachloro-1,4-benzoquinone $(\mathrm{Cl} 4 \mathrm{Q})^{16-20}$ and tetrabromo-1,4-benzoquinone (Br4Q), ${ }^{21,22}$ where radical anions can be stabilised under appropriate conditions, have also been designed. A crystallographic study of tetrachlorosemiquinone radical anion - in its well-known potassium salt3 - was attempted in

\footnotetext{
${ }^{a}$ Rudjer Bo_skovi_c Institute, Bijeni_cka 54, HR-10000 Zagreb, Croatia. E-mail: kmolcano@irb.hr

${ }^{b}$ Department of Physical Chemistry, Faculty of Science, University of Zagreb, Horvatovac 102a, HR-10002 Zagreb, Croatia

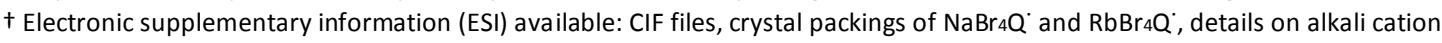
coordination, ORTEP drawings of cation coordination spheres and anions, experimental details on $\mathrm{Br}_{4} \mathrm{Q}$ and $\mathrm{RbBr}_{4} \mathrm{Q}^{\prime}$ measured at room temperature. CCDC reference numbers 815385-815391. For ESI and crystallographic data in CIF or other electronic format see DOI: 10.1039/c1ce05513e
} 
$1973^{23}$ using a film method (Weissenberg camera). However, due to an extremely weak diffraction of poor crystals the authors could only determine unit cells of two polymorphs at room temperature. Due to a low number of observed reflections (146 out of 1100 theoretically observable ones using $\mathrm{Cu}-\mathrm{Ka}$ radiation) the space groups were tentatively assigned. The alkali salts of tetrahaolgenosemiquinone with an anion radical can crystallise with organic solvents. ${ }^{24,25}$ It was discovered that the physical properties of the crystalline solvated forms are strikingly different to those of solvent-free forms. ${ }^{24,25}$ For acetone solvate of potassium tetrachlorosemiquinone, a very low paramagnetic susceptibility was observed. ${ }^{26}$ The change of physical properties of solvent-free potassium tetrachlorosemiquinone were detected by cooling the sample below the phase-transition temperature $(220 \mathrm{~K}) .^{6-8,25,26}$ The researchers involved in these studies did not managed to crystallise the desired compounds until Zanotti and Del $\mathrm{Pra}^{27}$ reported the crystal structure of an acetone solvate of potassium tetrachlorosemiquinone (room-temperature data) in 1980. The crystal structure of the lowtemperature phase of the potassium tetrachlorosemiquinone has not been reported, yet.

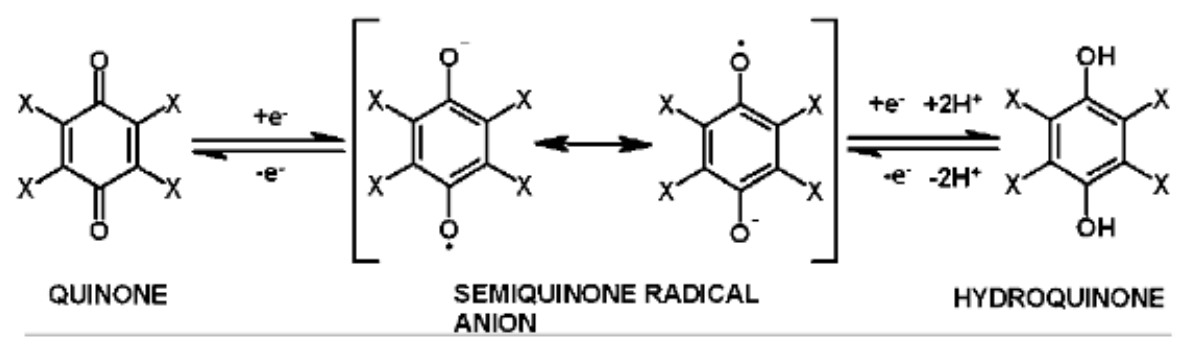

Scheme 1 Oxidation/reduction reactions of tetrahalogenquinones/tetrahalogenohydroquinones. $\mathrm{X}$ is $\mathrm{Br}$ or $\mathrm{Ci}$.

In the above mentioned studies, it is not always clear that chemical composition of samples was what was meant to be; the radical salts are dark-red but not green as described by Torrey and Hunter. ${ }^{3}$ The radicals easily disproportionate and turn from red to green colour. We provide evidence (details on sample preparation and X-ray structures) that the radical salts are dark-red and by quick decomposition in air at room temperature they turn into quinhydrones which are green compounds.

Semiquinones per se are generally not stable enough to form crystals suitable for $\mathrm{X}$ ray measurements. However, they can be stabilised by electron-transfer processes. Recently, several osemiquinone complexes with transition metals have been prepared; ${ }^{28-32}$ the crystal structure of unsubstituted p-benzosemiquinone radical stabilised by a low-barrier hydrogen bond was studied by X-ray diffraction and EPR spectroscopy. ${ }^{33}$ The electron transfer process significantly affects the electronic structure of the semiquinone radical and its geometry, both, $\mathrm{C}-\mathrm{O}$ bonds and quinoid ring skeleton. ${ }^{33-37}$

We report crystal structures of a series of alkali salts of tetrachloro and tetrabromosemiquinone radical anion $\left(\mathrm{Cl}_{4} \mathrm{Q}^{\cdot-}\right.$ and $\left.\mathrm{Br}_{4} \mathrm{Q}^{--}\right)$where the negative charge is balanced by an alkali cation (Scheme 2, Table 1). The radical anions are stabilised by spincoupling of unpaired electrons of contiguous tetrahalogenosemiquinone rings forming diamagnetic dimeric species as described by intermolecular association of charged $\pi$ radicals. ${ }^{38,39}$ 


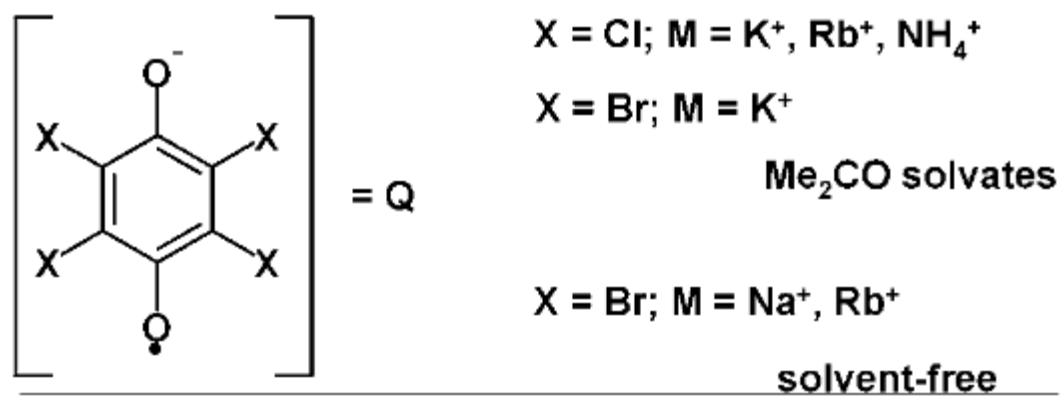

Scheme 2 Alkali salts of semiquinone radical anion discussed in this paper.

Table 1 List of compounds discussed in this paper ${ }^{a}$

\begin{tabular}{lllll}
\hline & $\mathrm{Na}^{+}$ & $\mathrm{K}^{+}$ & $\mathrm{Rb}^{+}$ & $\mathrm{NH}_{4}{ }^{+}$ \\
\hline $\mathrm{Cl}_{4} \mathrm{Q}^{-}$ & $\mathrm{N}$ & $\mathrm{S}$ & $\mathrm{S}$ & $\mathrm{N}$ \\
$\mathrm{Br}_{4} \mathrm{Q}^{-}$ & $\mathrm{A}$ & $\mathrm{S}$ & $\mathrm{A}$ &
\end{tabular}

${ }^{a} \mathrm{~S}$ : acetone solvates; A: solvent-free salts; N: salts prepared but crystals were too small and unstable to be used for X-ray measurement.

\section{Results and discussion}

\section{Colour changes are associated with redox reaction in the crystals}

Tetrachlorosemiquinone radical anion salts were considered to be green. ${ }^{3,7,23}$ However, the freshly precipitated sample (Fig. 1a) is dark-red; in air it turns to green. The green substance looks to be crystalline (Fig. 1b) but it does not diffract at all whereas darkred crystals diffract well. This finding explains 'poor crystallinity of the sample' reported by Konno et al.; ${ }^{23}$ the sample they measured was not crystalline. However, the green sample retains radical properties for several days.

The crystals quickly decompose in air due to a loss of acetone and eventually (after several days) disproportionate into a quinhydrone like salt of the formula $\mathrm{M}_{2} \mathrm{C}_{6} \mathrm{X}_{4} \mathrm{O}_{2} \$ \mathrm{C}_{6} \mathrm{X}_{4} \mathrm{O}_{2}$ ( $\mathrm{M}$ is an alkali metal and $\mathrm{X} \mathrm{Cl}, \mathrm{Br}$ ). Upon heating ${ }^{3}$ or long standing in air (weeks to months) the green salt is slowly oxidised back into tetrahalogenoquinone (yellow, Fig. 1b). An analogous example is p-benzosemiquinone/quinhydrone system; ${ }^{33}$ the radical crystals are red and the quinhydrone crystals are green. p-Benzosemiquinone precipitated from a protic solvent is red (radical) but disproportionates into quinhydrone (turns to green) within a few days. It has been a unique example of a reversible single crystalto-single crystal redox reaction. ${ }^{33}$

Crystals of acetone solvates: $\mathrm{KCl}_{4} \mathrm{Q} \cdot \mathrm{Me}_{2} \mathrm{CO}, \mathrm{RbCl}_{4} \mathrm{Q} \cdot \mathrm{Me}_{2} \mathrm{CO}$ and $\mathrm{KBr}_{4} \mathrm{Q} \cdot \mathrm{Me}_{2} \mathrm{CO}$ are very unstable. Thin plate-like crystals are formed 10-15 min after addition of solid alkali iodide into the solution of tetrahalogenoquinone (Fig. 1a). 


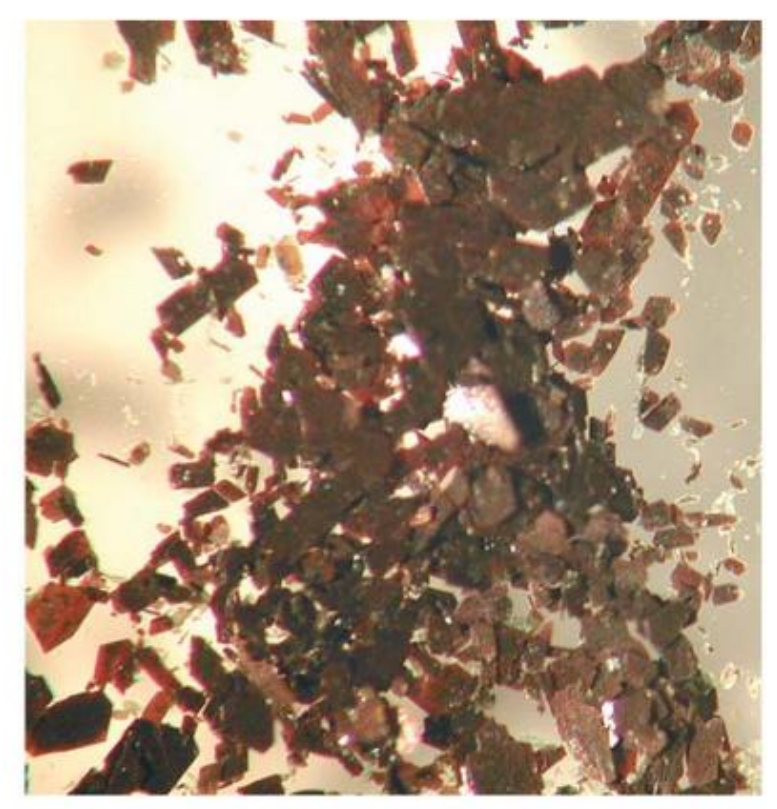

a)

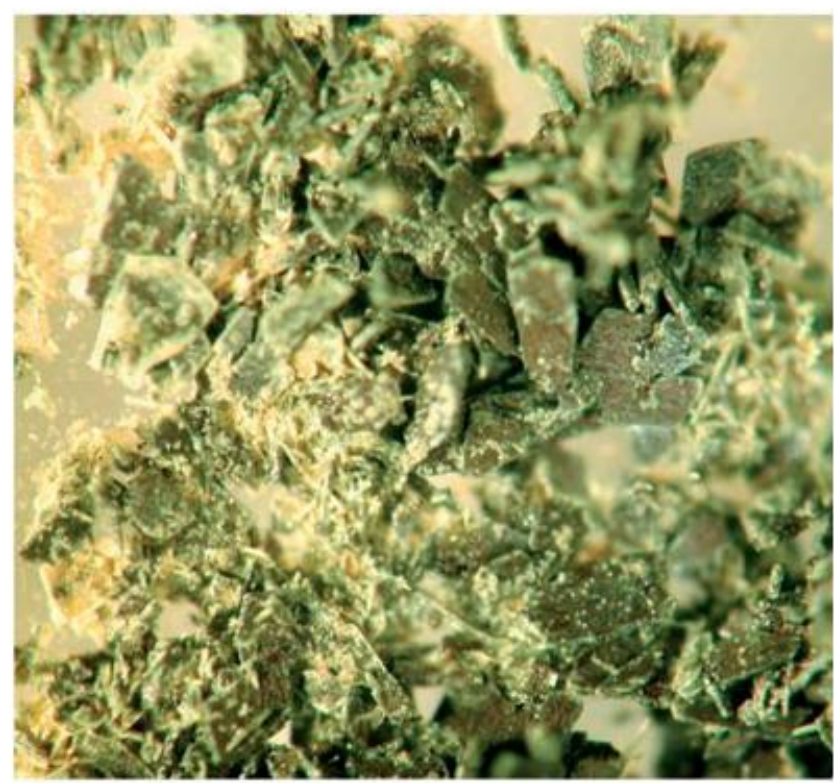

b)

Fig 1 Crystals of $\mathrm{KCl}_{4} \mathrm{Q} \cdot \mathrm{Me}_{2} \mathrm{CO}:$ a) immediately after removing from acetone solution, b) a several day-old dry sample of $\mathrm{KCl}_{4} \mathrm{Q}^{*}$ $\mathrm{Me}_{2} \mathrm{CO}$ turned to $\mathrm{K}_{2} \mathrm{C}_{6} \mathrm{Cl}_{4} \mathrm{O}_{2} \mathrm{C}_{6} \mathrm{Cl}_{4} \mathrm{O}_{2}$ (small yellow crystals are tetrachloroquinone).

The larger plates are stable in air for 2-3 min, just enough to be manipulated and flash-cooled, before decomposing into the green substance (Fig. 1b). Similar behaviour was observed for $\mathrm{NH}_{4} \mathrm{Cl}_{4} \mathrm{Q} \cdot \mathrm{Me}_{2} \mathrm{CO}$ and $\mathrm{NaCl}_{4} \mathrm{Q} \cdot \mathrm{Me}_{2} \mathrm{CO}$, however the full data sets for these two compounds could not be measured due to small size $(<0.02 \mathrm{~mm})$ and instability of the crystals. The unit cell parameters of the ammonium salt (see Experimental section) suggest isostructural relationship (at the level of non-hydrogen atoms) with the structures of $\mathrm{KCl} 4 \mathrm{Q}^{\cdot} \mathrm{Me} 2 \mathrm{CO}$, $\mathrm{RbCl}_{4} \mathrm{Q}^{\cdot} \mathrm{Me}_{2} \mathrm{CO}$ and $\mathrm{KBr}_{4} \mathrm{Q}^{\cdot} \mathrm{Me}_{2} \mathrm{CO}$.

Solvent-free salts, $\mathrm{NaBr}_{4} \mathrm{Q}^{\bullet}$ and $\mathrm{RbBr}_{4} \mathrm{Q}^{*}$ exposed to air are stable for $1-2$ days. Both compounds reveal similar crystal morphology. $\mathrm{RbBr}_{4} \mathrm{Q}^{\prime}$ sample is stable to survive even roomtemperature measurement (see Electronic Supplementary Information for details $\dagger$ ).

Although the stoichiometry gives the most direct evidence of the presence of the radical (a positive alkali cation must be balanced by an anion, $\mathrm{Cl}_{4} \mathrm{Q}^{--}$or $\mathrm{Br} 4 \mathrm{Q}^{--}$, which has an odd number of electrons: 111 and 193, respectively) an additional experimental evidence of unpaired electron was attempted by electron paramagnetic resonance (EPR) spectroscopy.

\section{Electron paramagnetic resonance spectroscopy}

The EPR spectra of single crystals of $\mathrm{KCl}_{4} \mathrm{Q}^{\cdot} \mathrm{Me}_{2} \mathrm{CO}, \mathrm{RbCl}_{4} \mathrm{Q}^{\cdot} \mathrm{Me}_{2} \mathrm{CO}$ (Fig. 2) and $\mathrm{KBr}_{4} \mathrm{Q}^{*}$ $\mathrm{Me}_{2} \mathrm{CO}$ were recorded at room temperature. The intensities of the recorded spectra of $\mathrm{KCl}_{4} \mathrm{Q}$ $\mathrm{Me}_{2} \mathrm{CO}$ and $\mathrm{RbCl}_{4} \mathrm{Q} \cdot \mathrm{Me}_{2} \mathrm{CO}$ were significantly smaller than the intensity of $\mathrm{KBr}_{4} \mathrm{Q}^{\cdot} \mathrm{Me}_{2} \mathrm{CO}$ (for a few orders of magnitude). The EPR spectra could be approximated with simple Lorentzian singlet lines. The spectra of $\mathrm{KCl}_{4} \mathrm{Q} \cdot \mathrm{Me}_{2} \mathrm{CO}$ and $\mathrm{RbCl}_{4} \mathrm{Q} \cdot \mathrm{Me}_{2} \mathrm{CO}$ show similar peak-to-peak line-widths, $W$ z $0.5 \mathrm{mT}$, with effective g-values, $g$ z 2.005 (Fig. 2) whereas the spectrum of $\mathrm{KBr}_{4} \mathrm{Q}^{\cdot} \mathrm{Me}_{2} \mathrm{CO}$ revealed broader singlet line, $W$ z 4 mT with $g$ z 2.011.

In order to investigate temperature behaviour of the employed compounds, the EPR spectra of the crystals were recorded in the temperature interval 295-360 K. The samples of $\mathrm{KCl}_{4} \mathrm{Q} \cdot \mathrm{Me}_{2} \mathrm{CO}$ and $\mathrm{RbCl}_{4} \mathrm{Q} \cdot \mathrm{Me}_{2} \mathrm{CO}$ show sudden increase in spectral intensity (by 1-2 orders of magnitude) at about $330 \mathrm{~K}$ and $350 \mathrm{~K}$, respectively (Fig. 2a and b); after heating these samples up to $360 \mathrm{~K}$ and cooling down to $295 \mathrm{~K}$, the signals exhibit a paramagnetic behaviour. The spectra of $\mathrm{KBr}_{4} \mathrm{Q}^{\cdot} \mathrm{Me}_{2} \mathrm{CO}$ revealed an intensity increase with $1 / T$ in the whole 
monitored temperature interval typical of paramagnetic dependence. The obtained EPR results support diamagnetic properties of $\mathrm{KCl}_{4} \mathrm{Q} \cdot \mathrm{Me}_{2} \mathrm{CO}$ and $\mathrm{RbCl}_{4} \mathrm{Q} \cdot \mathrm{Me}_{2} \mathrm{CO}$ at room temperature. Diamagnetism of these samples could be explained by coupling of unpaired electrons of two closely positioned radical anions (formation of a dimer) in their crystal packing (see section on Crystal packing). After heating of the samples, paramagnetic behaviour was detected (EPR signal became strong).

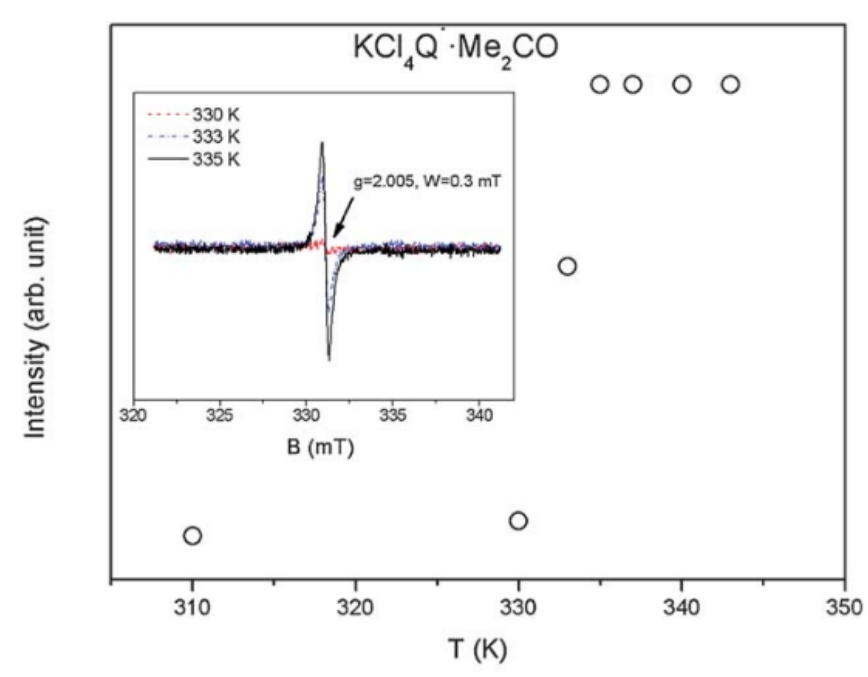

a)

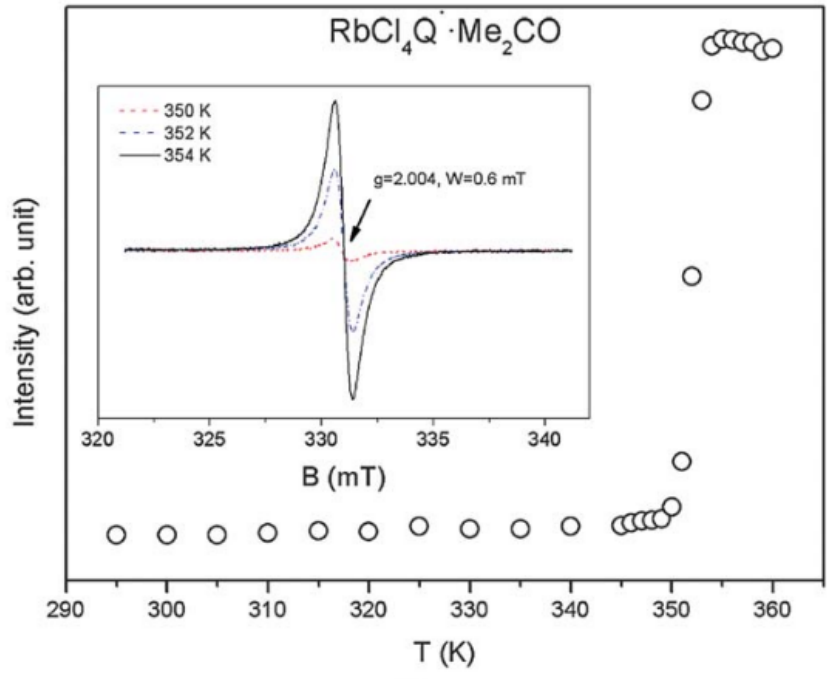

b)

Fig 2 Intensity of EPR signal as a function of temperature for the single crystal of a) $\mathrm{KCl}_{4}$ ' $\mathrm{Me} 2 \mathrm{CO}$ and b) RbCl4Q: Me2CO; Insert: EPR spectra recorded at temperatures around the transition from diamagnetic to paramagnetic state

However, $\mathrm{KBr}_{4} \mathrm{Q}^{\cdot} \mathrm{Me}_{2} \mathrm{CO}$ revealed a strong EPR signal already at room temperature, which can be assigned to paramagnetic state. This sample is unstable even at room temperature as revealed by X-ray diffraction data. The partially decomposed crystals yielded an inferior structure with high $\mathrm{R}$ and residual electron density (see Experimental section).

To understand change from diamagnetic to paramagnetic state the disintegration of a crystal was examined. The crystal structure of $\mathrm{KCl}_{4} \mathrm{Q} \cdot \mathrm{Me}_{2} \mathrm{CO}$ collapses upon loss of acetone at $325 \mathrm{~K}$ as determined by thermogravimetric and differential thermal analysis; the collapse of the crystal structure is also confirmed by a lack of diffraction pattern. Upon standing in air the solvate loses acetone, and becomes paramagnetic within a couple of hours. Single crystals begin to degrade a few minutes after removal from the solution. By disintegration of the crystal lattice, dimers do not survive any more and the monomeric anion radical, which is an electron carrier, survives for a certain period (several days in air and several months in a sealed tube) during which the paramagnetism is detected. Upon decomposition of the crystal lattice due to loss of acetone, uncoupling of electron spins took place and accordingly EPR signal gained in intensity that is characteristic of paramagnetic behaviour.

Quantum-chemical calculations were done for semiquinone radical pairs at short and long distances in the crystal structure of $\mathrm{KCl}_{4} \mathrm{Q} \cdot \mathrm{Me}_{2} \mathrm{CO}$. According to the results obtained by the broken symmetry DFT and the CAS-MP2 methods, for the pair at short distance, the antiferromagnetic singlet state is more stable than the triplet by 5.7 and $5.6 \mathrm{kcal} \mathrm{mol}^{-1}$, respectively. For the other pair, the triplet state was more stable by $0.01 \mathrm{kcal} \mathrm{mol}^{-1}$ (DFT) and by $3.3 \mathrm{kcal} \mathrm{mol}^{-1}$ (CAS-MP2). It supports the conclusion that the diamagnetic character at low temperatures is a consequence of the antiferromagnetic pairing, while a small increase of the 
distance between the adjacent anion radicals could invert the order of the singlet and triplet states and result with the occurrence of paramagnetism.

\section{Geometry of the semiquinone radical anion}

The anions reveal no crystallographic symmetry (Fig. 3) except in $\mathrm{NaBr}^{\circ} \mathrm{Q}^{*}$ (with an anion symmetry $\mathrm{Ci}$ ). In $\mathrm{NaBr} 4 \mathrm{Q}^{\circ}$ and $\mathrm{RbBr}^{\circ} \mathrm{Q}^{\circ}$ the rings are planar within experimental error, but in acetone solvates they are slightly puckered. Cremer-Pople ring puckering parameters $\tau^{40}$ for $\mathrm{Cl} 4 \mathrm{Q}^{--}$anions are $2.6\left(\mathrm{RbCl}_{4} \mathrm{Q}^{\circ} \mathrm{Me}_{2} \mathrm{CO}\right)$ and $2.8^{\circ}\left(\mathrm{KCl}_{4} \mathrm{Q}^{\cdot} \mathrm{Me}_{2} \mathrm{CO}\right)$; for $\mathrm{Br} 4 \mathrm{Q}^{--}$anions they are $3.4^{\circ}$ and $4.3^{\circ}\left(\mathrm{KBr}_{4} \mathrm{Q}^{\circ} \mathrm{Me}_{2} \mathrm{CO}\right)$. Puckering was also observed in the room temperature structure of $\mathrm{KCl}_{4} \mathrm{Q}^{\cdot} \mathrm{Me}_{2} \mathrm{CO}^{27}$ which occurs due to sterical hindrance of chlorine substituents.

Bond lengths in anions (Tables ${ }^{213,14,41,42}$ and $3^{43}$ ) agree well with theoretically predicted values; ${ }^{12-14,35,36}$ geometry of the semiquinone radical anion is more similar to a quinone than to a hydroquinone. In aromatic hydroquinone rings, all $\mathrm{C}-\mathrm{C}$ bonds are nearly equal, whereas in quinoid rings, well-defined single and double $\mathrm{C}-\mathrm{C}$ bonds occur. ${ }^{44} \mathrm{In}$ semiquinone radicals, $\mathrm{C} 2-\mathrm{C} 3$ and $\mathrm{C} 5-\mathrm{C} 6$ bonds are significantly longer (1.36-1.37 $\AA$ ) than double bonds in quinoid rings, while other four bonds (corresponding to single ones in quinoid rings) are significantly shorter $(1.45-1.46 \AA)$ than single $\mathrm{C}-\mathrm{C}$ bonds. $\mathrm{C}-\mathrm{O}$ bond lengths $(1.24-1.26 \AA)$ are also longer than double bonds observed in quinones, and the bond order is about 1.5. Their bond lengths varied more than bond lengths of carbon skeleton; in tetrabromosemiquinone, differences in $\mathrm{C}-\mathrm{O}$ bonds deviate about $0.03 \AA$ (Table 3 ) and these changes can be attributed to polarization of the anions by alkali cations.

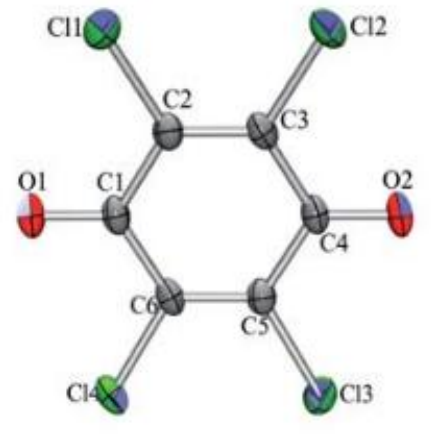

a)

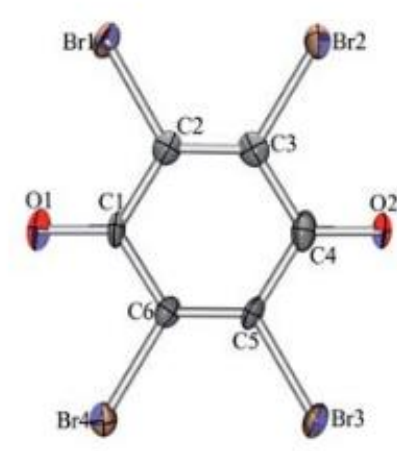

b)

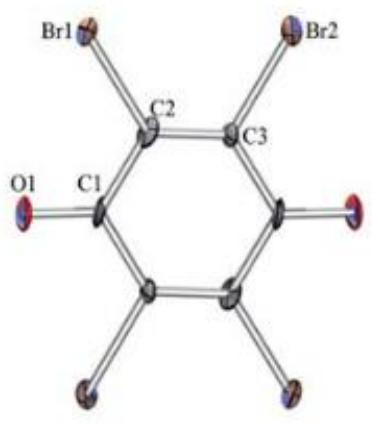

c)

Fig 3 ORTEP drawings of a) $\mathrm{Cl}_{4} \mathrm{Q}^{\cdot}$ anion $\mathrm{KCl}_{4} \mathrm{Q}^{\cdot} \cdot \mathrm{Me}_{2} \mathrm{CO}$, and $\mathrm{Br}_{4} \mathrm{Q}^{\cdot}$ anions in b) $\mathrm{RbBr}_{4} \mathrm{Q}^{\circ}$ and c) in $\mathrm{NaBr}_{4} \mathrm{Q}^{\circ}$ with atom numbering schemes (applied to all structures discussed). Displacement ellipsoids are drawn with the probability of $50 \%$. 
Aromaticity of tetrahaolgenosemiquinone radical anions was assessed by the component of a shielding tensor ${ }^{45}$ (nucleus independent chemical shift, NICS) that is orthogonal to the ring plane calculated along the axis perpendicular to the semiquinone ring and passing through its centroid (Fig. 4). The results were compared with the HOMA indices ${ }^{46}$ derived from the calculated bond lengths in the quinone ring. Both quantities are commonly used as quantitative aromaticity indicators. ${ }^{47,48}$ The aromaticity indicators were calculated for the neutral quinone, semiquinone radical anion and hydroquinone dianion both with the hydrogen atoms on the quinone ring left unsubstituted and substituted by $\mathrm{Cl}$ and $\mathrm{Br}$.

The NICS profiles for neutral quinone species are typical for nonaromatic molecules, ${ }^{45}$ while those for hydroquinone dianions are typical for aromatic species, although notably less aromatic than the prototype benzene. The profiles obtained for semiquinone molecules are halfway between these typical cases, as one could expect on the basis of the resonance structures in Scheme 1. The HOMA values (Table 4) display the same characteristics. Both indicators show increasing trend of aromaticity along the sequence $\mathrm{X} \mathrm{Br}<\mathrm{Cl}<\mathrm{H}$.

According to quantum chemical calculations, hydrogen bonds significantly influence geometry of $p$-benzosemiquinone radical anion: ${ }^{34-36} \mathrm{C}-\mathrm{O}$ bond is elongated and the geometry of the ring becomes more similar to a hydroquinone. Our recent crystallographic study showed that $p$-benzosemiquinone radical stabilised by two low-barrier hydrogen bonds is halfway between a quinone and a hydroquinone ring. ${ }^{33}$ These variations affect the ring geometry (Table 2) but also redox properties of the system which is interrelated to electrontransfer capacity.

\section{Crystal packing and p-stacking of the radical anions}

Description of the crystal packing of studied salts is focused on the structures of solvates revealing dimeric stacking of radical anions whereas solvent-free analogues $\mathrm{NaBr}_{4} \mathrm{Q}^{\circ}$ and $\mathrm{RbBr}_{4} \mathrm{Q}^{\circ}$ show entirely different crystal packing: in crystal packing of sodium salt there is stacking of anion radicals similar to those in aromatics $(\mathrm{Cg} / \mathrm{Cg}$ of $3.669 \AA$ and offset of 1.5 $\AA$ ) whereas in rubidium salt there is no stacking of anion radicals at all (details given in Electronic Supplementary Information†). Crystal structures of acetone solvates are characterised by columns of coordinated cations by $\pi$-stacked anions running parallel to the plane (100) (Fig. 5a and 6). The solvent molecules are packed between these layers. Lamellar shape of the crystals (Fig. 1a) is compatible with the layered crystal packing. Solvent (acetone) molecules are embedded in the crystal packing by weak $\mathrm{O} 3 / \mathrm{K}^{+} / \mathrm{Rb}^{+}$interactions. They occupy approximately $25 \%$ of the unit cell volume (Fig. 6).

Table 2 Bond lengths in tetrachlorosemiquinone radical anions presented in this paper. Experimental bond lengths in tetrachloroquinone $\left(\mathrm{Cl}_{4} \mathrm{Q}\right)^{41}$ and tetrachlorohydroquinone $\left(\mathrm{H}_{2} \mathrm{Cl}_{4} \mathrm{Q}\right)^{42}$ and theoretical bond lengths in $\mathrm{Cl}_{40} \mathrm{-}^{-}\left(\mathrm{CP}^{-\mathrm{PAW}}{ }^{13}\right)$ and $[\mathrm{B} 3 \mathrm{P} 86 / 6-31 \mathrm{G}(\mathrm{d})]^{14}$ are listed for comparison

\begin{tabular}{|c|c|c|c|c|c|c|}
\hline & $\mathrm{KCl}_{4} \mathrm{Q} \$ \mathrm{Me}_{2} \mathrm{CO}$ X-ray & $\mathrm{RbCl}_{4} \mathrm{Q} \$ \mathrm{Me}_{2} \mathrm{CO}$ X-ray & $\mathrm{Cl}_{4} \mathrm{Q} X-\mathrm{ray}^{41}$ & $\mathrm{H}_{2} \mathrm{Cl}_{4} \mathrm{Q} X-\mathrm{ray}^{42}$ & $\mathrm{Cl}_{4} \mathrm{Q}^{-}$CP-PAW ${ }^{13}$ & $\mathrm{Cl}_{4} \mathrm{Q}^{-} \mathrm{B} 3 \mathrm{P} 86^{14}$ \\
\hline $\mathrm{C} 1-\mathrm{C} 2$ & $1.458(2)$ & $1.451(3)$ & 1.488 & 1.386 & 1.458 & 1.458 \\
\hline $\mathrm{C} 2-\mathrm{C} 3$ & $1.361(3)$ & $1.366(3)$ & 1.344 & 1.357 & 1.371 & 1.371 \\
\hline $\mathrm{C} 3-\mathrm{C} 4$ & $1.457(2)$ & $1.463(3)$ & 1.490 & 1.400 & $1.458^{a}$ & $1.458^{a}$ \\
\hline $\mathrm{C} 4-\mathrm{C} 5$ & $1.454(3)$ & $1.447(3)$ & $1.488^{a}$ & $1.386^{a}$ & $1.458^{a}$ & $1.458^{a}$ \\
\hline C5-C6 & $1.365(3)$ & $1.372(3)$ & $1.344^{a}$ & $1.357^{a}$ & $1.371^{a}$ & $1.371^{a}$ \\
\hline $\mathrm{C} 6-\mathrm{Cl}$ & $1.450(3)$ & $1.458(3)$ & $1.490^{a}$ & $1.400^{a}$ & $1.458^{a}$ & $1.458^{a}$ \\
\hline $\mathrm{Cl}-\mathrm{O} 1$ & $1.249(2)$ & $1.250(3)$ & 1.211 & 1.349 & 1.244 & 1.244 \\
\hline $\mathrm{C} 4-\mathrm{O} 2$ & $1.243(2)$ & $1.248(3)$ & $1.211^{a}$ & $1.349^{a}$ & $1.244^{a}$ & $1.244^{a}$ \\
\hline $\mathrm{C} 2-\mathrm{C} 11$ & $1.722(2)$ & $1.724(2)$ & 1.702 & 1.743 & N/A & $\mathrm{N} / \mathrm{A}$ \\
\hline $\mathrm{C} 3-\mathrm{Cl} 2$ & $1.721(2)$ & $1.721(2)$ & 1.700 & 1.722 & $\mathrm{~N} / \mathrm{A}$ & $\mathrm{N} / \mathrm{A}$ \\
\hline $\mathrm{C} 5-\mathrm{Cl} 3$ & $1.721(2)$ & $1.719(2)$ & $1.702^{a}$ & $1.743^{a}$ & $\mathrm{~N} / \mathrm{A}$ & $\mathrm{N} / \mathrm{A}$ \\
\hline C6-Cl4 & $1.725(2)$ & $1.722(2)$ & $1.700^{a}$ & $1.722^{a}$ & $\mathrm{~N} / \mathrm{A}$ & $\mathrm{N} / \mathrm{A}$ \\
\hline
\end{tabular}


Table 3 Bond lengths in tetrabromosemiquinone radical anions. Bond lengths in tetrabromoquinone $\left(\mathrm{Br}_{4} \mathrm{Q}\right.$, details given in Electronic Supplementary Informationt) and tetrabromohydroquinone $\left(\mathrm{H}_{2} \mathrm{Br}_{4} \mathrm{Q}\right)^{43}$ are listed for comparison

\begin{tabular}{|c|c|c|c|c|c|c|}
\hline & $\mathrm{NaBr}_{4} \mathrm{Q}$ & $\mathrm{KBr}_{4} \mathrm{Q} \$ \mathrm{Me}_{2} \mathrm{CO}(\mathrm{A})$ & $\mathrm{KBr}_{4} \mathrm{Q} \$ \mathrm{Me}_{2} \mathrm{CO}(\mathrm{B})$ & $\mathrm{RbBr}_{4} \mathrm{Q}$ & $\mathrm{Br}_{4} \mathrm{Q}$ & $\mathrm{H}_{2} \mathrm{Br}_{4} \mathrm{Q}^{43}$ \\
\hline $\mathrm{C} 1-\mathrm{C} 2$ & $1.47(2)$ & $1.47(2)$ & $1.46(2)$ & $1.45(1)$ & $1.483(5)$ & 1.361 \\
\hline $\mathrm{C} 2-\mathrm{C} 3$ & $1.36(2)$ & $1.35(2)$ & $1.39(2)$ & $1.37(1)$ & $1.326(6)$ & 1.347 \\
\hline C3-C4 & $1.46(2)^{a}$ & $1.44(2)$ & $1.47(2)$ & $1.46(1)$ & $1.486(6)$ & 1.390 \\
\hline $\mathrm{C} 4-\mathrm{C} 5$ & $1.47(2)^{b}$ & $1.46(2)$ & $1.48(2)$ & $1.46(1)$ & $1.483(5)^{b}$ & $1.361^{b}$ \\
\hline C5-C6 & $1.36(2)^{b}$ & $1.34(2)$ & $1.34(2)$ & $1.35(1)$ & $1.326(6)^{b}$ & $1.347^{b}$ \\
\hline C6-Cl & $1.46(2)^{b}$ & $1.43(2)$ & $1.42(2)$ & $1.47(1)$ & $1.486(6)^{b}$ & $1.390^{b}$ \\
\hline $\mathrm{Cl}-\mathrm{Ol}$ & $1.25(2)$ & $1.27(2)$ & $1.25(1)$ & $1.231(9)$ & $1.207(6)$ & 1.366 \\
\hline $\mathrm{C} 4-\mathrm{O} 2$ & $1.25(2)^{b}$ & $1.26(1)$ & $1.24(2)$ & $1.232(9)$ & $1.207(6)^{b}$ & $1.366^{b}$ \\
\hline $\mathrm{C} 2-\mathrm{Br} 1$ & $1.86(1)$ & $1.88(1)$ & $1.88(1)$ & $1.878(9)$ & $1.880(4)$ & 1.882 \\
\hline $\mathrm{C} 3-\mathrm{Br} 2$ & $1.90(1)$ & $1.89(1)$ & 1.87 (1) & $1.887(9)$ & $1.883(4)$ & 1.894 \\
\hline $\mathrm{C} 5-\mathrm{Br} 3$ & $1.86(1)^{b}$ & $1.91(1)$ & 1.88 (1) & $1.887(8)$ & $1.880(4)^{b}$ & $1.882^{b}$ \\
\hline $\mathrm{C} 6-\mathrm{Br} 4$ & $1.90(1)^{b}$ & $1.90(1)$ & $1.89(1)$ & $1.894(8)$ & $1.883(4)^{b}$ & $1.894^{b}$ \\
\hline
\end{tabular}

The coordination polyhedra of $\mathrm{K}$ and $\mathrm{Rb}$ cations are bicapped trigonal prisms (see ESI for details $\dagger$ ). Rosokha et al. $^{49}$ examined how alkali cations affect p-interactions of anion radical dimers and observed three distinctive types of structural arrangements. The 'separated' dimers are characterised by large distances from cations which are nested in the crown-ether cavities. With the other two types, the cations are exposed and coordinated by oxygen atoms of semiquinone anions. So that 'tethered' dimers are bridged by the cations, whereas the 'non-tethered' do not involve bridging, and the cation simply balances the anion charge in the ratio $1: 1$. It has also been found that separated p-dimeric anion radicals exhibit longitudinal offset of the radical monomers (along the molecular $\mathrm{O}-\mathrm{O}$ axis), in contrast to the tethered arrangements with a transversal shift. As can be expected on the basis of these findings, the crystal structures of tetrachloro- and tetrabromosemiquinone potassium and rubidium acetone solvates reveal cation-tethered p-dimeric anion radicals (Fig. 5b) with transversal shifts of 0.84 and $1.18 \AA$, respectively. In these arrangements the shortest distance $\mathrm{K}^{+} / \mathrm{O} 1$ of $2.648(1) \AA$ and $\mathrm{Rb}{ }^{+} / \mathrm{O} 1$ of $2.759(2) \AA$ are observed (both contacts involve symmetry operated oxygen species: $\mathrm{x}, 1 / 2,-\mathrm{y},-1 / 2+\mathrm{z}$, see ESI for the complete coordination sphere†). 
Fig 4 NICS values calculated along the axes perpendicular to the quinone ring for the neutral quinone, radical anion - semiquinone, hydroquinone dianion and benzene molecule.

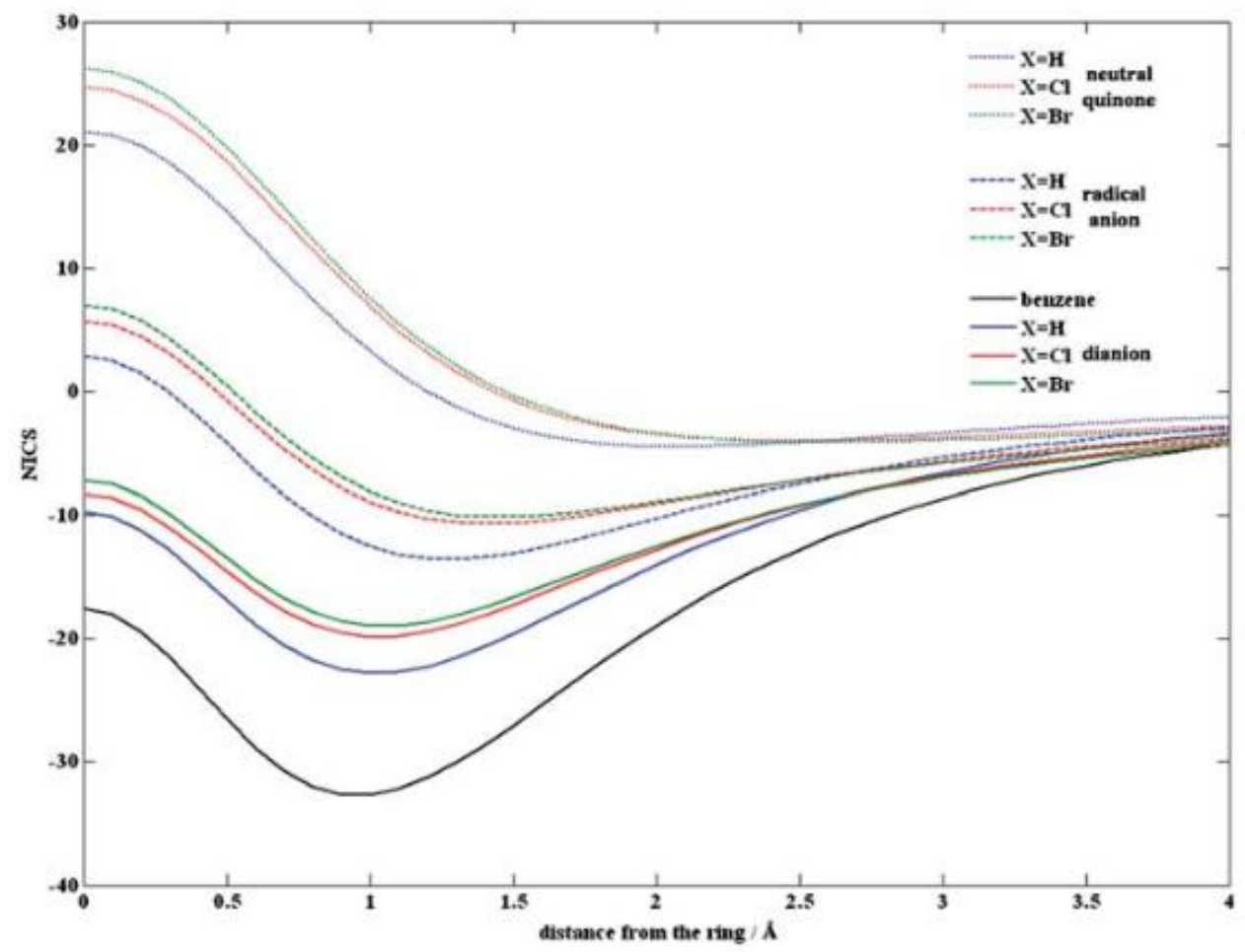

Table 4 The calculated C-C bond lengths within the quinoid rings and the HOMA values for various substituted quinoid species

\begin{tabular}{|c|c|c|}
\hline & Bond lengths & HOMA \\
\hline Benzene & $\mathrm{C}-\mathrm{C}: 1.39$ & 1.00 \\
\hline Dianion, $\mathrm{X}=\mathrm{Br}$ & $\begin{array}{l}\mathrm{C} 1-\mathrm{C} 2: 1.43 \\
\mathrm{C} 2-\mathrm{C} 3: 1.39\end{array}$ & 0.49 \\
\hline $\mathrm{X}=\mathrm{Cl}$ & $\begin{array}{l}\mathrm{C} 1-\mathrm{C} 2: 1.43 \\
\mathrm{C} 2-\mathrm{C} 3: 1.39\end{array}$ & 0.69 \\
\hline $\mathrm{X}=\mathrm{H}$ & $\begin{array}{l}\mathrm{C} 1-\mathrm{C} 2: 1.42 \\
\mathrm{C} 2-\mathrm{C} 3: 1.40\end{array}$ & 0.76 \\
\hline Radical anion, $\mathrm{X}=\mathrm{Br}$ & $\begin{array}{l}\mathrm{C} 1-\mathrm{C} 2: 1.45 \\
\mathrm{C} 2-\mathrm{C} 3: 1.36\end{array}$ & 0.21 \\
\hline $\mathrm{X}=\mathrm{Cl}$ & $\begin{array}{l}\mathrm{C} 1-\mathrm{C} 2: 1.45 \\
\mathrm{C} 2-\mathrm{C} 3: 1.37\end{array}$ & 0.25 \\
\hline $\mathrm{X}=\mathrm{H}$ & $\begin{array}{l}\mathrm{C} 1-\mathrm{C} 2: 1.44 \\
\mathrm{C} 2-\mathrm{C} 3: 1.36\end{array}$ & 0.43 \\
\hline Neutral, $\mathrm{X}=\mathrm{Br}$ & $\begin{array}{l}\mathrm{C} 1-\mathrm{C} 2: 1.49 \\
\mathrm{C} 2-\mathrm{C} 3: 1.34\end{array}$ & -1.00 \\
\hline $\mathrm{X}=\mathrm{Cl}$ & $\begin{array}{l}\mathrm{C} 1-\mathrm{C} 2: 1.49 \\
\mathrm{C} 2-\mathrm{C} 3: 1.34\end{array}$ & -0.95 \\
\hline$X=H$ & $\begin{array}{l}\mathrm{C} 1-\mathrm{C} 2: 1.48 \\
\mathrm{C} 2-\mathrm{C} 3: 1.33\end{array}$ & -0.61 \\
\hline
\end{tabular}




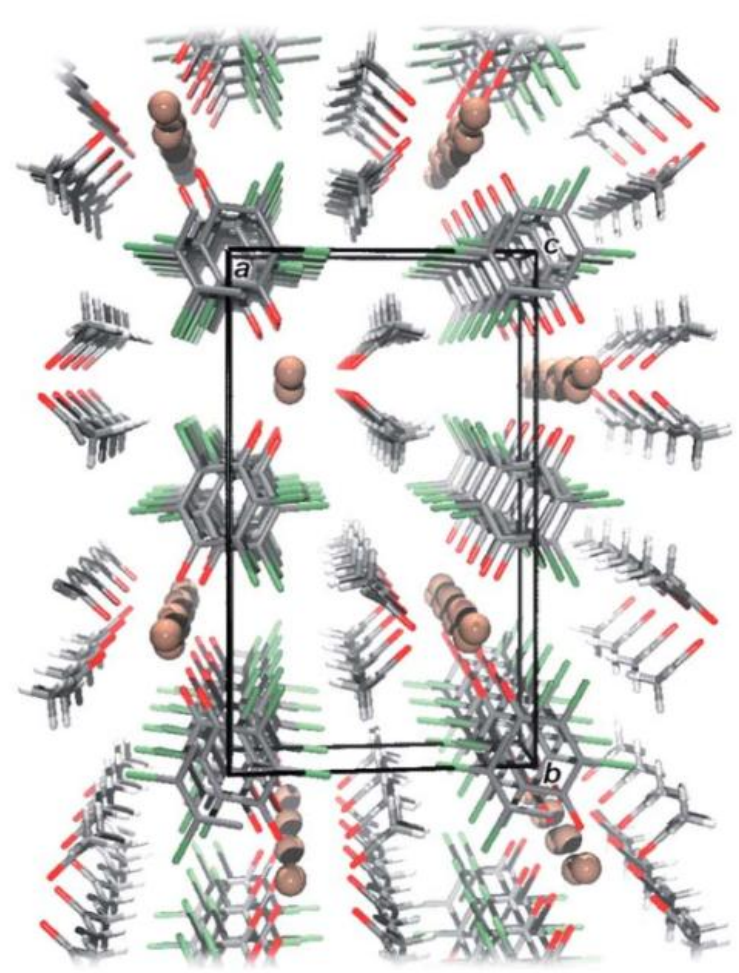

a)

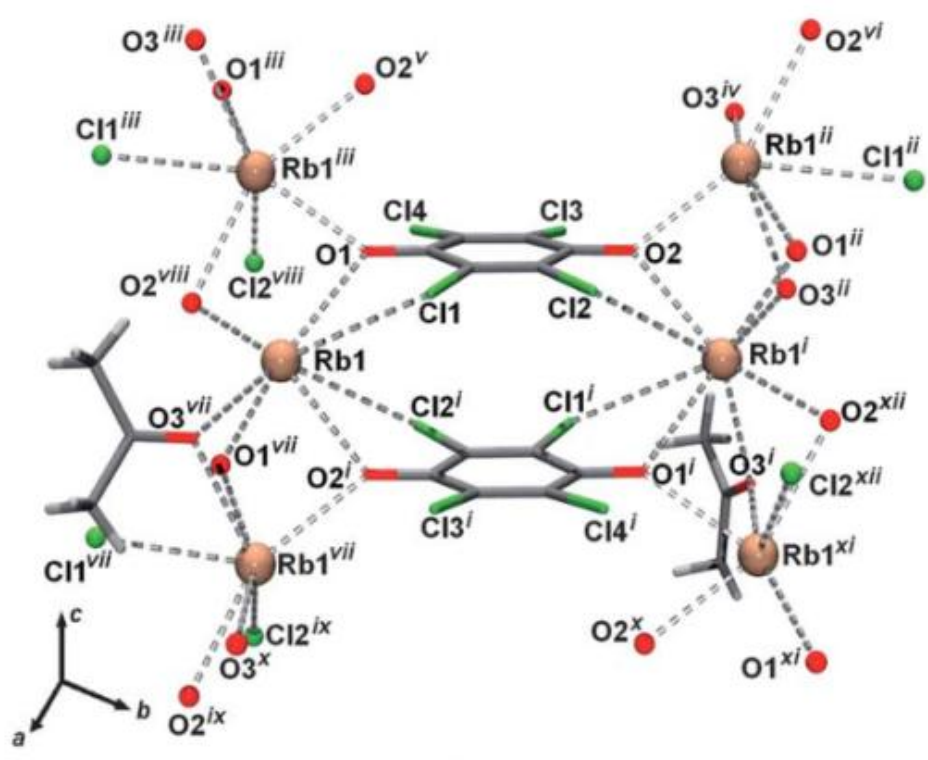

b)

Fig 5 a) Crystal packing of $\mathrm{RbCl}_{4} \mathrm{Q} \cdot \mathrm{Me}_{2} \mathrm{CO}$ viewed down the direction [001]. Acetone molecules are bound to cations by weak $03 \cdots \mathrm{Rb}^{+}$interactions and dispersion interactions connect the layers, which are parallel to (100). A fragment of cation-anion layer showing a cation-tethered dimer of semiquinone radical anions. Rubidium cations are depicted as spheres of arbitrary radii. Symmetry operators: i) $-x,-y,-z ;$ ii) $-x, y+1 / 2,-z+1 / 2$; iii) $x,-y+1 / 2, z+1 / 2$; iv) $x,-y+1 / 2, z+3 / 2 ; v)-x,-y,-1 / 2,-z+1 ; v i) x,-y$ $-1, z 1 / 2$; vii) $x,-y+1 / 2, z-1 / 2$; viii) $-x, y,-z+1 / 2$; ix) $-x, y,-z-1 / 2 ; x) x, y-1 / 2, z-1 ; x i)-x, y+1 / 2,-z-1 / 2 ; x i i) x,-y, z-1 / 2$.

Despite similar unit cell parameters (see Experimental section) and similar crystal packing, $\mathrm{KBr} 4 \mathrm{Q}$ \$Me2CO has triclinic symmetry whereas $\mathrm{Cl} 4 \mathrm{Q}^{*}$ salts are of monoclinic symmetry; $\mathrm{KCl} 4 \mathrm{Q} \$ \mathrm{Me} 2 \mathrm{CO}$ and $\mathrm{RbCl} 4 \mathrm{Q} \$ \mathrm{Me} 2 \mathrm{CO}$ are isomorphous. In $\mathrm{KBr} 4 \mathrm{Q} \$ \mathrm{Me} 2 \mathrm{CO}$ there are two symmetry-independent anions (labelled as A and B) and their ring planes are rotated by 50.7, and two symmetry-independent types of p-stacks occur (Fig. 7).

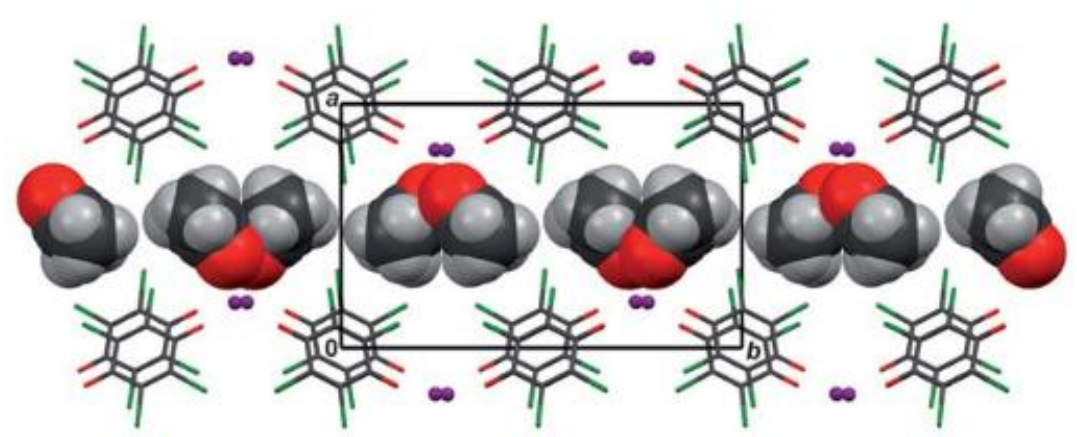

Fig 6 Crystal structure of $\mathrm{KCl}_{4} \mathrm{Q} \$ \mathrm{Me}_{2} \mathrm{CO}$ with acetone molecules depicted as space filling models. The solvent molecules occupy about $1 / 4$ of the unit cell volume. They embedded in the crystal packing by weak $03 \cdots \mathrm{K}^{+}$ interactions. 


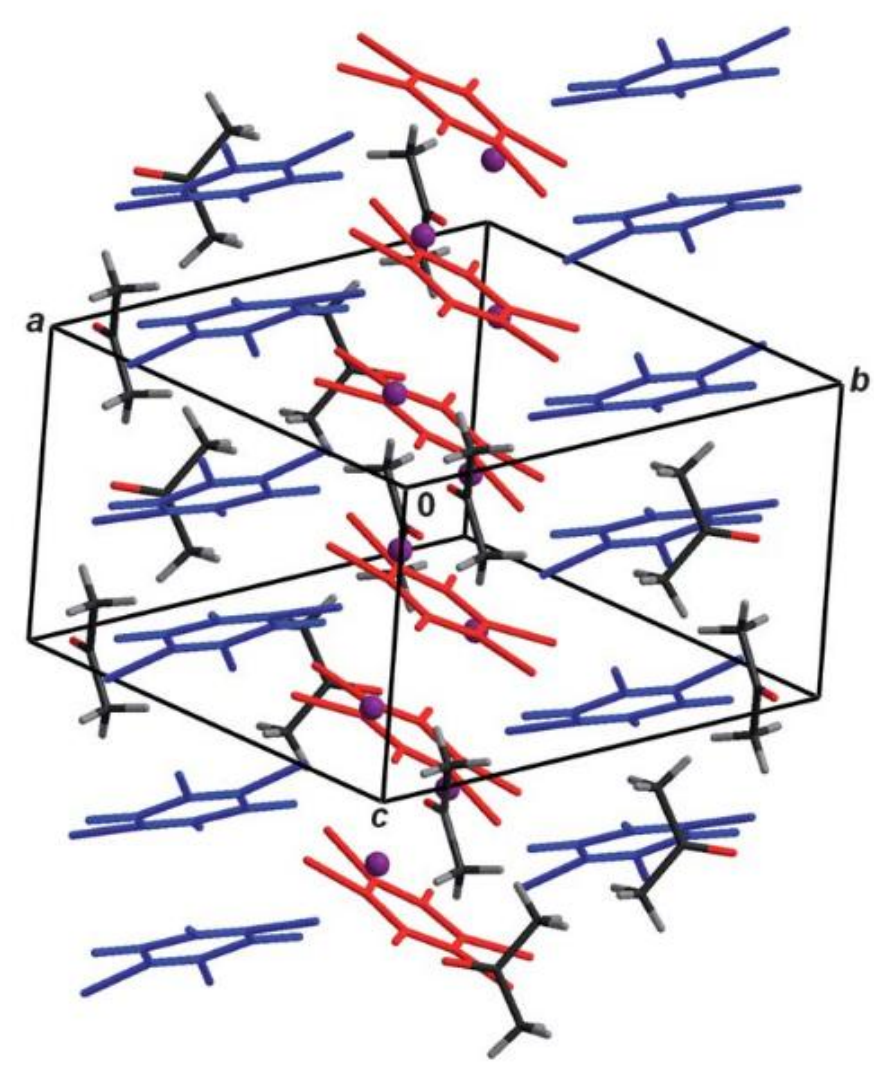

Fig $7 \mathrm{p}$-Stacks of tetrabromosemiquinone radical anions in the crystal packing of $K B r 4 Q^{-}$Me2CO. Each $p$-stack is formed by a single type of symmetry-independent anions ( $A$ in blue and $B$ in red). The angle between the mean planes of rings $A$ and $B$ is 50.7_. Potassium cations are depicted as spheres of arbitrary radii.

Table 5 Geometric parameters of the $\pi \cdots \pi$ interactions within dimeric radical anions in the low-temperature structures

\begin{tabular}{|c|c|c|c|c|c|c|}
\hline Structure & $\mathrm{Cg}^{a} \cdots \mathrm{Cg} / \AA$ & $\alpha^{b}$ & $\beta^{c}$ & $\mathrm{Cg} \cdots$ plane $(\mathrm{Cg} 2) / \AA$ & Offset/A & Symm. op. \\
\hline $\mathrm{KCl}_{4} \mathrm{Q} \cdot \mathrm{Me}_{2} \mathrm{CO}$ & 3.209 (1) & 0.00 & 15.41 & $3.0981(7)$ & 0.838 & $2-x,-y, 2-z$ \\
\hline $\mathrm{RbCl}_{4} \mathrm{Q} \cdot \mathrm{Me}_{2} \mathrm{CO}$ & $3.240(1)$ & 0.00 & 16.09 & $3.1129(9)$ & 0.898 & $2-x,-y, 2-z$ \\
\hline $\mathrm{KBr}_{4} \mathrm{Q} \cdot \mathrm{Me}_{2} \mathrm{CO}$ (A rings) & $3.204(7)$ & 0.00 & 17.24 & $3.060(5)$ & 0.950 & $1-x, 1-y, z$ \\
\hline $\mathrm{KBr}_{4} \mathrm{Q} \cdot \mathrm{Me}_{2} \mathrm{CO}$ ( $\mathrm{B}$ rings) & $3.307(7)$ & 0.00 & 20.84 & $3.091(5)$ & 1.177 & $2-x, 1-y, 1-z$ \\
\hline
\end{tabular}

${ }^{a} \mathrm{Cg}=$ centre of gravity of the aromatic ring. ${ }^{b} \alpha=$ angle between planes of two aromatic rings. ${ }^{c} \beta=$ angle between $\mathrm{Cg} \cdots \mathrm{Cg}$ line and normal to the plane of the first ring.

However, in $\mathrm{Cl}_{4} \mathrm{Q}^{-}$salts all anions are symmetry-related and parallel (Fig. 5 and 6).

$\pi$-Stacks of anions, running in the direction [001] (Fig. 5-7), are the most striking feature of the crystal structures of acetone solvates. They comprise pairs of stacked rings with the intra-pair centroid-centroid distances of $3.2 \AA$, only (Table 5); the close carbon-carbon contacts are $0.3 \AA$ shorter than the sum of van der Waals radii. However, these dimers are stacked further by very weak interactions (centroid distances between pairs are $>4.3 \AA$ ). The rings are slightly offset (Table 5), but less than usual in pstacks of aromatic rings (typical centroid and carbon/carbon distances are 3.6-4.1 $\AA$ and typical offsets are $1.6-1.8 \AA) .{ }^{50-55} \mathrm{In}$ acetone solvate of $\mathrm{KCl}_{4} \mathrm{Q}^{\circ}$, the change from a stack of radical anions to the stack of dimers is a temperature dependent rearrangement that affects the magnetic properties of this salt. ${ }^{25,27} \mathrm{In}$ the room-temperature phase ${ }^{27}$ the centroid distances of anion radicals are 3.46 and $4.16 \AA$, whereas in low-temperature phase $(150 \mathrm{~K})$ these values are 3.20 and $4.38 \AA$. A face-to-face stacking of quinoid rings with short centroid distances (about $3.3 \AA$ ) and no offset has already 
been described by us ${ }^{56,57}$ however, those quinoid rings were not radicals. Semiquinone anion rings are somewhere in between quinoid and aromatic character. $\pi$-Electrons are neither localised nor completely delocalised as in aromatic rings (Tables 2 and 3 ).

Interactions of delocalised p-systems are therefore attractive rather than repulsive due to the coupling of unpaired electrons which is confirmed by the lack of the EPR signal at room temperature. Electron-coupling of two adjacent tetrahaolgenosemiquinone radicals (characterised as dimers) is also observed in several crystals with $\pi$-stacked organic radicals. $^{58-61}$

Table 6 Crystallographic, data collection and structure refinement details

\begin{tabular}{|c|c|c|c|c|c|c|}
\hline Compound & $\mathrm{KCl}_{4} \mathrm{Q} \cdot \mathrm{Me}_{2} \mathrm{CO}$ & $\mathrm{RbCl}_{4} \mathrm{Q} \cdot \mathrm{Me}_{2} \mathrm{CO}$ & $\mathrm{KBr}_{4} \mathrm{Q} \cdot \mathrm{Me}_{2} \mathrm{CO}$ & $\mathrm{NaBr}_{4} \mathrm{Q}$ & $\mathrm{RbBr}_{4} \mathbf{Q}^{\prime}$ & $\mathrm{NH}_{4} \mathrm{Cl}_{4} \mathrm{Q} \cdot \mathrm{Me}_{2} \mathrm{CO}$ \\
\hline Empirical formula & $\mathrm{C}_{9} \mathrm{H}_{6} \mathrm{Cl}_{4} \mathrm{KO}_{3}$ & $\mathrm{C}_{9} \mathrm{H}_{6} \mathrm{Cl}_{4} \mathrm{O}_{3} \mathrm{Rb}$ & $\mathrm{C}_{9} \mathrm{H}_{6} \mathrm{Br}_{4} \mathrm{O}_{3} \mathrm{~K}$ & $\mathrm{C}_{6} \mathrm{Br}_{4} \mathrm{O}_{2} \mathrm{Na}$ & $\mathrm{C}_{6} \mathrm{Br}_{4} \mathrm{O}_{2} \mathrm{Rb}$ & $\mathrm{C}_{9} \mathrm{H}_{10} \mathrm{Cl}_{4} \mathrm{NO}_{3}$ \\
\hline Formula wt/g mol-1 & 343.04 & 389.41 & 566.48 & 446.67 & 509.17 & 321.99 \\
\hline Colour & Red & Red & Red & Red & Red & Red \\
\hline Crystal dimensions/mm & $0.25 \times 0.13 \times 0.04$ & $0.26 \times 0.16 \times 0.12$ & $0.09 \times 0.05 \times 0.01$ & $0.08 \times 0.05 \times 0.01$ & $0.17 \times 0.04 \times 0.02$ & $0.03 \times 0.02 x<0.01$ \\
\hline Space group & $P 2{ }_{1} / \mathrm{c}$ & $P 2_{1} / \mathrm{c}$ & $P \overline{\mathrm{l}}$ & $P 2_{1} / n$ & $P 2_{1} 2_{1} 2_{1}$ & undetermined \\
\hline a/A & $10.4655(1)$ & $10.4749(1)$ & $7.5940(2)$ & $8.1909(3)$ & $4.3340(1)$ & $10.62(1)$ \\
\hline b/A & $16.7229(2)$ & $16.9600(1)$ & $10.6229(4)$ & $3.6689(3)$ & $13.5784(3)$ & $16.95(1)$ \\
\hline$c / \mathrm{A}$ & $7.4574(1)$ & $7.6663(1)$ & $16.9280(5)$ & $15.5125(6)$ & $17.4009(3)$ & $7.579(9)$ \\
\hline$\alpha p$ & 90 & 90 & $91.426(3)$ & 90 & 90 & $91.13(8)$ \\
\hline$\beta / \circ$ & $102.892(1)$ & $103.267(1)$ & $91.085(3)$ & $97.7123)$ & 90 & $100.7(1)$ \\
\hline$\gamma p$ & 90 & 90 & $100.728(3)$ & 90 & 90 & $91.47(8)$ \\
\hline $\mathrm{Z}$ & 4 & 4 & 4 & 2 & 4 & 4 \\
\hline$V / \mathrm{A}^{3}$ & $1272.25(3)$ & $1325.60(2)$ & $1340.92(7)$ & $461.96(5)$ & $1024.02(4)$ & 1339 \\
\hline$D_{\mathrm{d}} \mathrm{g} \mathrm{cm}^{-3}$ & 1.791 & 1.951 & 2.580 & 3.211 & 3.303 & \\
\hline$\mu / \mathrm{mm}^{-1}$ & 11.345 & 12.518 & 17.399 & 21.425 & 24.666 & \\
\hline$\Theta$ range $^{\circ}$ & $4.33-75.00$ & $4.34-75.00$ & $2.61-76.34$ & $5.76-75.95$ & $3.89-66.12$ & \\
\hline$T / \mathrm{K}$ & $150(2)$ & $100(2)$ & $100(2)$ & $100(2)$ & $100(2)$ & $100(2)$ \\
\hline Diffractometer type & Xcalibur Nova & Xcalibur Nova & Xcalibur Nova & Xcalibur Nova & Xcalibur Nova & Xcalibur Nova \\
\hline \multirow[t]{3}{*}{ Range of $h, k, l$} & $-12<h<13$ & $-13<h<13$ & $-9<h<9$ & $-9<h<10$ & $-4<h<5$ & \\
\hline & $-18<k<20$ & $-21<k<21$ & $-12<k<13$ & $-4<k<4$ & $-16<k<15$ & \\
\hline & $-8<1<9$ & $-9<l<9$ & $-21<l<21$ & $-18<l<19$ & $-15<l<21$ & \\
\hline Reflections collected & 6336 & 7000 & 13053 & 2253 & 5013 & \\
\hline Independent reflections & 2601 & 2704 & 5485 & 939 & 2041 & \\
\hline Observed reflections $(I \geq 2 \sigma)$ & 2400 & 2519 & 4898 & 784 & 1953 & \\
\hline Absorption correction & Multi-scan & Multi-scan & Multi-scan & Multi-scan & Multi-scan & \\
\hline$T_{\min }, T_{\max }$ & $0.1980 ; 0.6350$ & $0.2200 ; 0.1303$ & $0.8400 ; 0.1570$ & $0.8036 ; 0.0858$ & $1.0000 ; 0.10845$ & \\
\hline$R_{\text {int }}$ & 0.0284 & 0.0255 & 0.0504 & 0.0433 & 0.0453 & \\
\hline$R(F)$ & 0.0369 & 0.0333 & 0.0787 & 0.0720 & 0.0430 & \\
\hline$R_{\mathrm{w}}\left(F^{2}\right)$ & 0.0962 & 0.0898 & 0.2330 & 0.2649 & 0.1115 & \\
\hline Goodness of fit & 1.040 & 1.074 & 1.096 & 1.092 & 1.104 & \\
\hline $\mathrm{H}$ atom treatment & Free & Constrained & Constrained & None & None & \\
\hline No. of parameters, restraints & 178,0 & 154,4 & 305,18 & 61,6 & 118,0 & \\
\hline$\Delta \rho_{\max }, \Delta \rho_{\min } / \mathrm{e} \mathrm{A}^{-3}$ & $0.555 ;-0.364$ & $0.980 ;-1.075$ & $4.776 ;-1.423$ & $3.789 ;-2.570$ & $1.359 ;-0.917$ & \\
\hline
\end{tabular}

\section{Conclusions}

Dimers of tetrahaolgenosemiquinone anion-radical rings with the separation distance of ring centroids of $3.2 \AA$ with offset less than $1 \AA$ are the dominant motif in crystal structures of alkali salts $\left(\mathrm{K}^{+}\right.$and $\left.\mathrm{Rb}^{+}\right)$of tetrahaolgenosemiquinone anion radical acetone solvates. The close stacking of dimers is characterised by the coupling of two unpaired electrons from the two contiguous radical anions. The diamagnetic property of their crystals is in agreement with lack of the EPR signal.

The layers of stacked radical-anion rings are connected by van der Waals interactions with solvent molecules into the threedimensional crystal structures. About a quarter of the unit cell volume is occupied by solvent molecules and their interactions, although weak, are essential for crystal packing and their magnetic properties. 
However, in the crystal packing of solvent-free alkali salts of tetrahaolgenosemiquinone anion radicals the motifs are different. In $\mathrm{NaBr}_{4} \mathrm{Q}^{\circ}$, there is stacking of anion radicals similar to those occurring in aromatics whereas for crystal packing

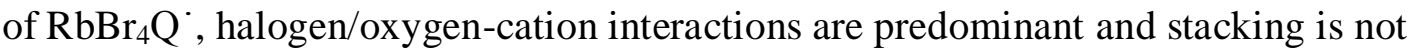
observed. It is obvious that lack of solvent leads to more compact packing that does not leave enough space for organisation of radical anion dimers. To design crystals of different magnetic properties one can modulate the size of cation and polarity and size of solvent molecule.

According to the geometric parameters and NICS profiles, tetrachloro- and tetrabromosemiquinone rings exhibit intermediate aromaticity in between the aromatic hydroquinone dianion and nonaromatic neutral quinone.

\section{Experimental}

\section{Preparation of the samples}

All substances (alkali iodides and tetrahalogenoquinones, acetone) were purchased from commercial sources (Merck, Sigma-Aldrich, Kemika) and were of p.a. grade. The samples were prepared according to the method described by Torrey and Hunter. ${ }^{3}$ Excess of solid alkali iodide was added to a nearly saturated solution of $\mathrm{Cl}_{4} \mathrm{Q}$ or $\mathrm{Br}_{4} \mathrm{Q}$ in cold acetone (277 $\mathrm{K})$. Crystals large enough for X-ray measurement would appear in 10-15 min, but would decompose in the solution within the next hour (acetone solvates even faster).

A reaction of $\mathrm{Cl}_{4} \mathrm{Q}$ and $\mathrm{KI}$ was performed in cold methanol and the system behaved similarly to that in acetone, however the plate-like crystals (probably methanol solvate of $\left.\mathrm{KCl}_{4} \mathrm{Q}\right)$ were too small $(<0.01 \mathrm{~mm})$ and extremely unstable and inappropriate for X-ray measurements. The reason might be low solubility of $\mathrm{Cl}_{4} \mathrm{Q}$ in methanol.

\section{Data collection and structure determination}

The unstable radical crystals required low-temperature measurements (Table 6). The short life-time of crystals of acetone solvates in air (2-3 min) was just enough to select single crystals under a stereomicroscope, glue them to a glass needle and mount into a stream of cold nitrogen gas.

Single crystal measurements were performed on an Oxford Diffraction Xcalibur Nova $\mathrm{R}$ diffractometer (microfocus Cutube, CCD detector) equipped with an Oxford Instruments Cryojet liquid nitrogen cooling device. Program package CrysAlis $\mathrm{PRO}^{62}$ was used for data reduction and multi-scan absorption correction. The structures were solved using SHELXS97 ${ }^{63}$ and refined with SHELXL97. ${ }^{63}$ The models were refined using the full-matrix least squares refinement; all nonhydrogen atoms were refined anisotropically. Hydrogen atoms were located from difference Fourier map and refined as free entities for $\mathrm{KCl}_{4} \mathrm{Q} \cdot \mathrm{Me}_{2} \mathrm{CO}$; in other solvates they were treated as riding entities. The atomic scattering factors were those included in SHELXL97. ${ }^{63}$ Molecular geometry calculations were performed by PLATON, ${ }^{64}$ and molecular graphics were prepared using ORTEP- $3,{ }^{65}$ and CCDC-Mercury. ${ }^{66}$ Crystallographic and refinement data for the structures reported in this paper are shown in Table 6.

Supplementary crystallographic data for this paper can be obtained free of charge via www.ccdc.cam.ac.uk/conts/retrieving. html (or from the Cambridge Crystallographic Data Centre, 12, Union Road, Cambridge CB2 1EZ, UK; fax: +44 1223 336033; or deposit@ccdc.cam.ac.uk). CCDC 815385-815391 contain the supplementary crystallographic data for this paper. 


\section{EPR spectroscopy}

Room-temperature EPR measurements were performed on a Bruker Elexsys $580 \mathrm{FT} / \mathrm{CW}$ spectrometer at the microwave frequency $9.6 \mathrm{GHz}$ with the magnetic field modulation amplitude of $0.1 \mathrm{mT}$ at $100 \mathrm{kHz}$. Temperature-dependent EPR measurements were performed on a Varian E-9 spectrometer (at $9.3 \mathrm{GHz}$ ) equipped with a Bruker variable temperature unit (ER 4111 VT), using liquid nitrogen for heating and cooling samples. Since crystals showed nearly isotropic signal they were placed inside sealed glass capillaries to minimise exposure to oxygen from air. The air inside capillaries was saturated with acetone vapours, preventing further evaporation of acetone (and decomposition of crystals) from acetone-containing compounds. The procedure applied, enables the highly sensitive samples to be preserved for several days to several weeks.

\section{Ab initio calculations}

All calculations were done with the program package Gaussian $03^{67}$ and the basis set 6$311++\mathrm{G}(2 \mathrm{~d}, 2 \mathrm{p})$. When not taken from crystallographic results, the geometries were optimized by using the B3P86 functional. ${ }^{68,69}$ Optimized geometries were confirmed as minima on the potential energy surface by computation of the Hessian eigenvalues. Nucleus independent chemical shifts were calculated by the GIAO method ${ }^{70,71}$ with the Hartree-Fock wavefunction. Calculations for radical species were performed with unrestricted molecular orbitals. Singlet and triplet energies of the pairs of semiquinone radical anions were assessed by the broken symmetry DFT (with the B3LYP functional ${ }^{68,72}$ ) and by the MCSCF method with the minimum active space spanned by the HOMO and LUMO orbitals. Intermolecular interaction was estimated by adding MP2 calculation to the CAS result.

\section{Acknowledgements}

This work was supported by Ministry of Science, Education and Sports of Croatia grants numbers 098-1191344-2943, 098- 0982915-2950, and 098-0982915-2939. TG/DTA analysis of decomposition of $\mathrm{KCl}_{4} \mathrm{Q} \cdot \mathrm{Me}_{2} \mathrm{O}$ was performed by Lidija Andro_s and Ernest Sanders (RBI). IR spectrum of $\mathrm{RbBr}_{4} \mathrm{Q}^{*}$ was measured by Dr Marijana Jurić (RBI).

\section{Notes and references}

1 Q. Guo, J. T. Corbett, G. Yue, Y. C. Fann, S. Y. Qian, K. B. Tomer and R. P. Mason, J. Biol. Chem., 2002, 277, 6104-6110.

2 S. Y. Reece and D. G. Nocera, Annu. Rev. Biochem., 2009, 78, 673-600.

3 H. A. Torrey and W. H. Hunter, J. Am. Chem. Soc., 1912, 34, 702-716.

4 Y. Matsunaga, Can. J. Chem., 1960, 38, 1172-1176.

5 J. J. André, J. Clementz, R. Jesser and G. Weill, C.R. Acad. Sci. B, 1968, 266, 1057-1060.

6 J. J. André and G. Weill, C.R. Acad. Sci. B, 1969, 269, 499-502.

7 J. J. André and G. Weill, Mol. Phys., 1968, 15, 97-99.

8 A. Girlando, I. Zanon, R. Bozio and C. Pecile, J. Chem. Phys., 1978, 68, $22-31$.

9 G. N. R. Tripathi, J. Chem. Phys., 1981, 74, 6044-6049.

10 G. N. R. Tripathi and R. H. Schuler, J. Phys. Chem., 1983, 87, 3101-3105.

11 R. H. Schuler, G. N. R. Tripathi, M. F. Prebenda and D. M. Chipman, J. Phys. Chem., 1983, 87, 5357-5361.

12 S. E. Boesch and R. A. Wheeler, J. Phys. Chem., 1995, 99, 8125-8134. 
13 C. Katan, P. E. Bl€ochl, P. Margl and C. Koenig, Phys. Rev. B: Condens. Matter, 1996, 53, 12112-12120.

14 S. E. Boesch and R. A. Wheeler, J. Phys. Chem. A, 1997, 101, 8351-8359.

15 P. J. O’Malley, Antioxid. Redox Signaling, 2001, 3, 825-838.

16 A. Girlando, L. Morelli and C. Pecile, Chem. Phys. Lett., 1973, 22, 553-558.

17 M. LeCointe, M. H. Lemée, H. Cailleau, B. Toudic, L. Toupet, G. Heger, F. Moussa, P. Schweiss, K. H. Kraft and N. Karl, Phys. Rev. B: Condens. Matter, 1995, 51, 3374-3386.

18 T. Del Giacco, F. Elisei and O. Lanzalunga, Phys. Chem. Chem. Phys., 2000, 2, 17011708.

19 T. Murata, Y. Morita, Y. Yakizama, K. Fukui, H. Yamochi, G. Saito and K. Nakasuji, J. Am. Chem. Soc., 2007, 129, 10837-10846.

20 S. Horiuchi, R. Kumai and Y. Tokura, Chem. Commun., 2007, 2321-2329.

21 S. Horiuchi, Y. Okimoto, R. Kumai and Y. Tokura, J. Am. Chem. Soc., 2001, 123, 665670.

22 P. Garc_1a, S. Dahaoui, P. Fertey, E. Wenger and C. Lecomte, Phys. Rev. B: Condens. Matter Mater. Phys., 2005, 72, 104115.

23 M. Konno, H. Kobayashi, F. Marumo and Y. Saito, Bull. Chem. Soc. Jpn., 1973, 46, 1987-1990.

24 S. Hiroma and T. Kuroda, Bull. Chem. Soc. Jpn., 1974, 47, 3014-3020.

25 T. Sugano,T.Ohta andH.Kuroda, Chem.Phys.Lett., 1975, 34, 164-166.

26 J. J. Andr_e and G. Weill, Chem. Phys. Lett., 1971, 9, 27-30.

27 G. Zanotti and A. Del Pra, Acta Crystallogr., Sect. B: Struct. Crystallogr. Cryst. Chem., 1980, B36, 313-316.

28 N. Shaikh, S. Goswami, A. Panja, X.-Y. Wang, S. Gao, R. J. Butcher and P. Banerjee, Inorg. Chem., 2004, 43, 5908-5918.

29 P. Gupta, A. Das, F. Basuli, A. Castineiras, W. S. Sheldrick, H. Mayer-Figge and S. Bhattacharya, Inorg. Chem., 2005, 44, 2081-2088.

30 A. V. Piskunov, A. V. Lado, G. A. Abakumov, V. K. Cherkasov, O. V. Kuznetsova, G. K. Fukin and E. V. Baranov, Russ. Chem. Bull., 2007, 56, 97-103.

31 K. S. Min, A. G. DiPasquale, J. A. Golen, A. L. Rheingold and J. S. Miller, J. Am. Chem. Soc., 2007, 129, 2360-2368.

32 A. M. Morris, C. G. Pierpoint and R. G. Finke, Inorg. Chem., 2009, 48, 3496-3498.

33 K. Molčanov, B. Kojić-Prodić and M. Roboz, Acta Crystallogr., Sect. B: Struct. Sci., 2006, B62, 1051-1060.

34 P. J. O’Malley and S. J. Collins, Chem. Phys. Lett., 1996, 259, 296-300.

35 P. J. O’Malley, J. Phys. Chem. A, 1997, 101, 6334-6338.

36 P. J. O’Malley, J. Phys. Chem. A, 1997, 101, 9813-9817.

37 T.-J. Lin and P. J. O’Malley, THEOCHEM, 2008, 870, 31-35.

38 J.-M. Lü, S. V. Rosokha and J. K. Kochi, J. Am. Chem. Soc., 2003, 125, 12161-12171. 
39 J.-M. Lü, S. V. Rosokha, I. S. Neretin and J. K. Kochi, J. Am. Chem. Soc., 2006, 128, $16708-16719$.

40 D. Cremer and J. A. Pople, J. Am. Chem. Soc., 1975, 97, 1354-1358.

41 K. J. van Weperen and G. J. Visser, Acta Crystallogr., Sect. B: Struct. Crystallogr. Cryst. Chem., 1972, 28, 338.

42 T. Sakurai, Acta Crystallogr., 1962, 15, 443-447.

43 V. R. Thalladi, H.-C. Weiss, R. Boese, A. Nangia and G. R. Desiraju, Acta Crystallogr., Sect. B: Struct. Sci., 1999, 55, 1005-1013.

44 S. Hünig, Pure Appl. Chem., 1990, 62, 395-406.

45 A. Stanger, J. Org. Chem., 2006, 71, 883-893.

46 T. M. Krygowski and M. Cyra_nski, Tetrahedron, 1996, 52, 1713-1722.

47 P. Lazzeretti, Phys. Chem. Chem. Phys., 2004, 6, 217-223.

48 Y. Morita, J. Kawai, K. Fukui, S. Nakazawa, K. Sato, D. Shiomi, T. Takui and K. Nakasuji, Org. Lett., 2003, 5, 3289-3291.

49 S. V. Rosokha, J. Lu, T. Y. Rosokha and J. K. Kochi, Phys. Chem. Chem. Phys., 2009, 11, 324-332.

50 C. A. Hunter and C. A. Sanders, J. Am. Chem. Soc., 1990, 112, 5525-55234.

51 C. A. Hunter, K. R. Lawson, J. Perkins and C. J. Urch, J. Chem. Soc., Perkin Trans., 2001, 651-669.

52 E. A. Mayer, R. K. Castellano and F. Diedrich, Angew. Chem., Int. Ed., 2003, 42, 12101250.

53 J. K. Klosterman, Y. Yamauchi and M. Fujita, Chem. Soc. Rev., 2009, 38, 1714-1725.

54 J. W. Steed, J. L. Atwood, Supramolecular Chemistry, J. Wiley \& Sons, Chichester, U.K., 2000.

55 C. Janiak, J. Chem. Soc., Dalton Trans., 2000, 3885-3896.

56 K. Molčanov, B. Kojić-Prodić and A. Meden, CrystEngComm, 2009, 11, 1407-1415.

57 K. Molčanov, I. Sabljić and B. Kojić-Prodić, CrystEngComm., 2011, 13, 4211-4217.

58 W. Fujita and K. Awaga, Science, 1999, 286, 261-262.

59 M. E. Itkis, X. Chi, A. W. Cordes and R. C. Haddon, Science, 2002, 296, 1443-1445.

60 R. C. Haddon, A. Sarkar, S. K. Pal, X. Chi, M. E. Itkis and F. S. Tham, J. Am. Chem. Soc., 2008, 130, 13683-13690.

61 S. Oguri, O. Hanado, J. Takdea, M. Furuya, K. Ohno, S. Inoue and T. Kodaira, J. Lumin., $2005,112,283-286$.

62 CrysAlis PRO, Oxford Diffraction Ltd., U.K., 2007.

63 G. M. Sheldrick, Acta Crystallogr., Sect. A: Found. Crystallogr., 2008, 64, 112-122.

64 A. L. Spek, J. Appl. Crystallogr., 2003, 36, 7-13.

65 L. J. Farrugia, J. Appl. Crystallogr., 1997, 30, 565-565.

66 C. F. Macrae, P. R. Edgington, P. McCabe, E. Pidcock, G. P. Shields, R. Taylor, M. Towler and J. van de Streek, J. Appl. Crystallogr., 2006, 39, 453-457. 
67 M. J. Frisch, G. W. Trucks, H. B. Schlegel, G. E. Scuseria, M. A. Robb, J. R. Cheeseman, J. A. Montgomery Jr., T. Vreven, K. N. Kudin, J. C. Burant, J. M. Millam, S. S. Iyengar, J. Tomasi, V. Barone, B. Mennucci, M. Cossi, G. Scalmani, N. Rega, G. A. Petersson, H. Nakatsuji, M. Hada, M. Ehara, K. Toyota, R. Fukuda, J. Hasegawa, M. Ishida, T. Nakajima, Y. Honda, O. Kitao, H. Nakai, M. Klene, X. Li, J. E. Knox, H. P. Hratchian, J. B. Cross, V. Bakken, C. Adamo, J. Jaramillo, R. Gomperts, R. E. Stratmann, O. Yazyev, A. J. Austin, R. Cammi, C. Pomelli, J. W. Ochterski, P. Y. Ayala, K. Morokuma, G. A. Voth, P. Salvador, J. J. Dannenberg, V. G. Zakrzewski, S. Dapprich, A. D. Daniels, M. C. Strain, O. Farkas, D. K. Malick, A. D. Rabuck, K. Raghavachari, J. B. Foresman, J. V. Ortiz, Q. Cui, A. G. Baboul, S. Clifford, J. Cioslowski, B. B. Stefanov, G. Liu, A. Liashenko, P. Piskorz, I. Komaromi, R. L. Martin, D. J. Fox, T. Keith, M. A. Al-Laham, C. Y. Peng, A. Nanayakkara, M. Challacombe, P. M. W. Gill, B. Johnson, W. Chen, M. W. Wong, C. Gonzalez, J. A. Pople, Gaussian 03, revision E.01; Gaussian, Inc.: Wallingford, CT, 2004.

68 A. D. Becke, J. Chem. Phys., 1993, 98, 5648-5652.

69 J. P. Perdew, Phys. Rev. B, 1986, 33, 8822-8824.

70 K. Wolinski, J. F. Hilton and P. Pulay, J. Am. Chem. Soc., 1990, 112, 8251-8560.

71 J. R. Cheeseman, G. W. Trucks, T. A. Keith and M. J. Frisch, J. Chem. Phys., 1996, 104, 5497-5509.

72 C. Lee, W. Yang and R. G. Parr, Phys. Rev. B, 1988, 37, 785-789. 